\title{
EXPERIMENTAL DETERMINATION OF THE INFLUENCE OF FRESH CONCRETE'S COMPOSITION ON ITS RESISTANCE TO WATER AND DE-ICING CHEMICALS BY MEANS OF TWO METHODS
}

\author{
UPORABA DVEH METOD ZA EKSPERIMENTALNO DOLOČANJE \\ VPLIVA SESTAVE SVEŽEGA BETONA NA NJEGOVO \\ ODPORNOST NA VODO IN NA KEMIKALIJE ZA \\ PREPREČEVANJE ZMRZOVANJA
}

\author{
Dalibor Kocáb, Tereza Komárková, Monika Králíková, Petr Misák, \\ Bronislava Moravcová \\ Brno University of Technology, Faculty of Civil Engineering, Department of Building Testing, Veveří 95, 60200 Brno, Czech Republic \\ kralikova.m@fce.vutbr.cz
}

Prejem rokopisa - received: 2015-07-22; sprejem za objavo - accepted for publication: 2016-06-06

doi: $10.17222 /$ mit.2015.233

Concrete's durability is currently a frequently discussed topic. The determination of concrete's durability is rather difficult since it depends on a number of factors, out of which the surface-layer quality is very important. One of the options for assessing its quality is the determination of concrete's resistance to water and de-icing chemicals. The testing is based on loading the concrete by cyclic freezing and thawing during the simultaneous action of a thawing solution. The damage to the surface layer manifests itself as scaling, i.e., the loss of small scales from the surface of the material. The resistance of concrete to water and de-icing chemicals can be determined by means of several methods; however, a universal method of evaluation has not yet been established in Europe. The goal of the experiment described here was to assess the influence of fresh concrete's composition on its resistance to water and de-icing chemicals using two different measurement methods (method A and C). A total of 9 fresh concrete mixtures were designed, from which specimens were made. The experiment was created and evaluated using the statistical method DOE (Design of Experiment). Based on the tests performed, it can be stated that a change in the content of cement and plasticiser in fresh concrete is visible in the results of both methods. However, more so in the results for method C, which is generally more sensitive to changes in fresh concrete's composition.

Keywords: concrete, resistance, durability, de-icing chemicals

Zdržljivost betona je pogosto obravnavana tema. Določanje zdržljivosti betona je precej težko, ker je odvisno od številnih faktorjev, med katerimi je pomembna tudi kvaliteta površinske plasti. Ena od opcij določanja njene kvalitete, je določanje odpornosti betona na vodo in na kemikalije proti zmrzovanju. Preizkus temelji na izpostavitvi betona cikličnemu zamrzovanju in odtaljevanju s simultanim delovanjem raztopine za odtaljevanje. Poškodbe površinskega sloja se kažejo kot luščenje površine materiala. Odpornost betona na vodo in kemikalije za raztaljevanje se lahko določi z več metodami; vendar pa univerzalna metoda za oceno tega v Evropi še ni vzpostavljena. Cilj opisanih eksperimentov je bil oceniti vpliv sestavo svežega betona glede na njegovo odpornost na vodo in na kemikalije za raztaljevanje, z uporabo dveh metod (metoda A in C). Skupno je bilo pripravljenih 9 svežih betonskih mešanic iz katerih so bili izdelani vzorci. Eksperimenti so bili postavljeni in izvedeni z uporabo statistične metode DOE (postavitev preizkusa). Na podlagi izvedenih preizkusov se lahko zaključi, da se spremembe v vsebnosti cementa in plastifikatorja v svežem betonu pokažejo pri obeh metodah. Vendar so bolj izrazite pri rezultatih metode $\mathrm{C}$, ki je na splošno bolj občutljiva na spremembe v sestavi svežega betona.

Ključne besede: beton, odpornost, zdržljivost, kemikalije za odtajevanje

\section{INTRODUCTION}

The surface layer of concrete determines the condition of the structure during its service life, since it is exposed to environmental attack and its parameters show how well it can protect the concrete element and its reinforcement. ${ }^{1,2}$ The quality of the surface layer is very important for an assessment of the resistance of the concrete to external attack and especially for the total durability of the concrete. ${ }^{3}$ The term surface layer is not yet clearly defined. Generally speaking, it is a layer of approximately $20 \mathrm{~mm}$ to $50 \mathrm{~mm}$ from the surface, i.e., a concrete cover. ${ }^{4}$ The quality of the concrete cover is closely linked with its porosity, which, next to permeability, also influences its other properties. ${ }^{1}$ Porosity is influenced mainly by the amount of water needed for cement hydration, air voids produced by inadequate concrete compaction or by air-entrainment (content, size and distribution of air voids), cracks formed during hydration due to volume changes and other factors. ${ }^{5-7}$

The quality of the surface layer together with the porosity of the concrete also determines its resistance to the intrusion of liquids and gases from the environment, i.e., permeability. Permeability is determined, e.g., by TPT ${ }^{5-8}$, GWT and ISAT. ${ }^{9}$ Other options for assessing the surface layer of concrete are methods for determining the 
resistance of cement concrete to water and de-icing chemicals. The damage to concrete due to the action of de-icing chemicals manifests itself as the loss of small pieces of the material's surface; a phenomenon that is defined as scaling. ${ }^{10}$ Scaling can also be defined as damage to the surface caused by frost and a salt solution. It must be emphasised that the mechanism of scaling is not analogous to the conventional action of frost that causes ice crystals to form in the internal structure and thus decreases the stiffness and strength. Scaling occurs on the surface, which does not endanger the quality of the material within the concrete body; however, it makes concrete susceptible to water and aggressive agents entering its structure, which puts the overall resistance of the concrete in danger. ${ }^{10}$ Previous studies show that the damage to the surface layer of concrete is the most severe when the water contains a particular amount of the dissolved substance (known as pessimum concentration). ${ }^{11}$ The pessimum concentration is almost independent of the nature of the dissolved substance (e.g. salt, alcohol, urea - all these act similarly). ${ }^{12}$ The damage to the surface layer occurs in the form of small flakes or scales coming loose from the surface. ${ }^{10}$ Scaling itself does not occur without free liquid present on the concrete surface (even when the concrete is saturated with water in a dry environment and is exposed to cyclic freezing and thawing). The damage to the concrete surface is greater when the temperature of the loading cycle is lower. ${ }^{13}$ The salt concentration in the liquid acting upon the surface is more important than the concentration of salt solutions in the pores of the internal structure of the concrete. ${ }^{11}$ The resistance of concrete to freezing and thawing in the presence of de-icing salts is very low; however, it can be significantly increased by the addition of an air-entraining additive. ${ }^{14}$ The presence of air-entraining additives reduces the damage to the surface layer of concrete. ${ }^{12,15-16}$ However, next to the positive influence on frost resistance, concrete airentrainment also results in a decrease in the compressive strength; increasing air entrainment by one percent corresponds to a loss of 28-day compressive strength of about $5 \% .{ }^{17}$

Freeze-thaw resistance during the simultaneous action of a solution is described in the European standard CEN/TS 12390-9 ${ }^{18}$ (based on the Swedish standard SS $137244^{19}$ ). In the Czech Republic, the effect of water containing dissolved salts being frozen and thawed on concrete bodies is addressed in ČSN $731326 .{ }^{20}$ The action of frost in terms of damage to the internal structure is also dealt with in ČSN $731380^{21}$ and the determination of the frost resistance of concrete is in ČSN 73 $1322 .{ }^{22}$ Other methods worth mentioning are the American standard ASTM C 672/C 672M - 0323and the test method CDF according to RILEM, which is a part of the standard. ${ }^{18}$

The aim of the paper is an experimental determination of the influence of fresh concrete composition on its resistance to water and de-icing chemicals. This is done by means of two methods.

\section{TEST METHODS}

The basic principle of all methods for determining the resistance of concrete to water and de-icing chemicals is in essence the same. The concrete specimens are placed in an environmental chamber with automatic cycling, where they are exposed to the attack of demineralised water or defrosting chemicals for a cyclic alternation of temperatures above and below $0{ }^{\circ} \mathrm{C}$. The differences between these methods are mainly in the required number of cycles, minimum and maximum temperatures, the size of specimens and the area exposed, the direction in which the water and de-icing chemicals act on the specimens and in the interpretation of the obtained result. The testing procedures of the methods for the assessment of the freeze-thaw resistance of concrete are briefly described in the sections below. Only the procedures according to ${ }^{24}$ are discussed in greater detail as they are not known internationally.

\subsection{Procedure according to CEN/TS 12390-9}

This reference test method ${ }^{18}$ (hereafter called the scaling method) is based on the Swedish standard. ${ }^{19}$ However, it contains some modifications. The test requires four specimens with the dimensions of $50 \times 150 \times 150 \mathrm{~mm}$ cut from four $150-\mathrm{mm}$ concrete cubes. Next, $67 \mathrm{ml}$ of a $3 \% \mathrm{NaCl}$ solution is poured onto a sawed face of the specimen (the solution reaches up to $3 \mathrm{~mm}$ of the specimen height) and afterwards, the freeze-thaw cycles are initiated - the freezing stage lowers the temperature to $(-20 \pm 2){ }^{\circ} \mathrm{C}$ and during thawing it rises to $(+20 \pm 4){ }^{\circ} \mathrm{C}$. One cycle takes $24 \mathrm{~h}$. The freezethaw resistance is then evaluated by measuring the mass of the material scaled off the specimen surface after $7 \pm 1$, $14 \pm 1,28 \pm 1,42 \pm 1$ and 56 freeze-thaw cycles. ${ }^{18-19}$

\subsection{Procedure according to ASTM C672 / C672M - 12}

This testing method according to ${ }^{23}$ is concerned with a determination of the resistance of the horizontal surface layer of concrete exposed to cyclic freezing to the temperature of $-18 \pm 3{ }^{\circ} \mathrm{C}$ and thawing to $+23 \pm 2{ }^{\circ} \mathrm{C}$ in the presence of de-icing chemicals. The test requires a minimum of two specimens at least $75 \mathrm{~mm}$ high with the testing surface of a minimum area of $0.045 \mathrm{~m}^{2}$. Prior to the test, a $4 \% \mathrm{CaCl}_{2}$ solution is poured onto the specimen surface (6 mm layer of the solution). A different solution can also be used if its effect during cyclic temperature loading is being examined. For instance, the authors of ${ }^{25}$ used a $3 \%$ solution of $\mathrm{NaCl}$ and the authors of ${ }^{26}$ used a $4 \%$ solution $\left(\mathrm{NaCl}+\mathrm{CaCl}_{2}, 7: 3\right)$. One cycle also takes $24 \mathrm{~h}$. The state of the surface layer is only assessed visually after every 5 cycles, while the test takes 50 cycles in total. The assessment scale is from 0 (no 
scaling) to 5 (severe scaling = coarse aggregate is visible throughout the surface). ${ }^{23}$

\subsection{Procedure according to the CDF method}

This is an alternative method described in ${ }^{18}$. The minimum number of specimens is five and they have the shape of a half-cube. According to the standard ${ }^{18}$, the specimens must be made using special moulds. However, in ${ }^{27}$ the authors claim that sawing a $150-\mathrm{mm}$ cube into two roughly the same parts is sufficient. The principle of the test is the action of a $3 \% \mathrm{NaCl}$ solution on the specimen that is immersed in the solution with its level reaching up to $10 \pm 1 \mathrm{~mm}$. The temperature cycles consist of changes between $-20 \pm 0.5{ }^{\circ} \mathrm{C}$ and $+20 \pm 1{ }^{\circ} \mathrm{C}$ twice a day; one cycle takes $12 \mathrm{~h}$. The scales coming loose from the specimens are weighed after $4 \pm 1,6 \pm 1,14 \pm 1$ and $28 \pm 1$ freeze-thaw cycles. The test is evaluated by calculating the total amount of material scaled off the test surface after the above-mentioned number of freeze-thaw cycles. $^{18}$

\subsection{Procedure according to ČSN 731326}

The standard ČSN $731326^{20}$ is intended for concretes exposed to the action of salt and de-icing chemicals. Despite the fact that it contains three options of performing the test, currently only methods A (automatic cycling I) and C (automatic cycling II) are used. The difference between these two methods is mainly in the direction in which the $3 \% \mathrm{NaCl}$ solution acts. In the case of method $\mathrm{A}$, the specimen is immersed in the solution, similarly to the CDF method. ${ }^{18}$ In the case of method C, the solution is poured onto the top surface of the specimen, which makes the test similar to the scaling test according to ${ }^{18}$ and the method according to ${ }^{23}$. Both methods are discussed in the following sections.

\subsection{1 ČSN 731326 Method A}

The test is performed with three specimens, $150 \mathrm{~mm}$ cubes, which are made and cured according to ${ }^{28,29}$. At the age of 28 days, the automatic cycling test is begun where the unmodified top surface of the specimen is tested. The individual specimens are placed into noncorrosive containers, which enable their immersion in a 3 $\% \mathrm{NaCl}$ solution up to $5 \pm 1 \mathrm{~mm}$. The containers also collect the scaled-off material. During thermal loading, the surface of the specimens must be cooled from $+20{ }^{\circ} \mathrm{C}$ to $-15{ }^{\circ} \mathrm{C}$ in $45 \mathrm{~min}$ to $50 \mathrm{~min}$. It must then be warmed again within the same time and the maximum and minimum temperatures must be maintained for $15 \mathrm{~min}$. One cycle takes approximately $2 \mathrm{~h}$. After every $25^{\text {th }}$ cycle, the mass of the material scaled off the surface of the specimens in a dry state is determined. The resistance of the surface of the cement concrete to water and defrosting chemicals is determined either by the mass of the scaled off material per area in $\mathrm{g} / \mathrm{m}^{2}$ after a certain number of cycles or by the number of cycles necessary for $(1000,2000$ or 3000$) \mathrm{g} / \mathrm{m}^{2}$ of concrete to scale off.

\subsection{2 ČSN 731326 Method C}

The basic test specimen is a 50 -mm-thick layer cut off from the top surface of a concrete cylinder of diameter $150 \mathrm{~mm}$. The cylinder can be cast or coredrilled from a structure. Each specimen is fitted with a ring so that approximately a 5-mm-thick layer of a $3 \%$ $\mathrm{NaCl}$ solution can be poured onto its surface. Afterwards, the specimens are exposed to freeze-thaw cycles with minimum temperatures of $-18{ }^{\circ} \mathrm{C}$ for $3 \mathrm{~h}$ and maximum $+5{ }^{\circ} \mathrm{C}$ also for $3 \mathrm{~h}$. Thus, one cycle takes $6 \mathrm{~h}$. After every $25^{\text {th }}$ cycle, the particles lost from the tested surface in the dry state are weighed. The resistance of the concrete surface to defrosting chemicals is evaluated according to the D1 criterion (number of cycles necessary for the scale-off to reach $1000 \mathrm{~g} / \mathrm{m}^{2}$ ) through D5 (number of cycles necessary for scale-off to be 5000 $\left.\mathrm{g} / \mathrm{m}^{2}\right)$.

\section{EXPERIMENTAL PART AND MATERIAL}

The focus of the project GAČR 13-18870S is the research in concrete durability determined primarily by its surface layer quality. A number of papers have been published within the project, such as ${ }^{30-34}$. This paper describes one of the experiments conducted as part of the project. It involves the experimental assessment of the dependence of the resistance of concrete cover to the attack of water and de-icing chemicals on the amount of cement and plasticiser. The experiment was designed using the DOE (Design Of Experiment) method. ${ }^{35}$

A total of four groups of concretes with different cement contents were made (Table 1). They differed in the content of Portland cement CEM I 42.5 R. The concrete mixtures were then modified by the addition of a varied amount of plasticiser. The amount of water was adjusted so that the same workability was maintained. The other components of the fresh concretes were identical throughout the experiment, i.e. the same types of aggregate from the same location and the same type of cement from one cement mill. A large number of specimens were made from each type of concrete, amounting to approximately $0.4 \mathrm{~m}^{3}$ in total volume. In order to ensure the homogeneity of all the concrete specimens

Table 1: Concrete-mixture identification Tabela 1: Identifikacija mešanice betona

\begin{tabular}{|c|c|c|c|c|}
\hline \multicolumn{2}{|c|}{ Mixture } & \multicolumn{3}{c|}{$\begin{array}{c}\text { Percentage of plasticiser content } \\
\text { relative to } \\
\text { the mass of cement in the mixture, } \\
\text { in mass fractions }(w / \%)\end{array}$} \\
\cline { 3 - 5 } \multicolumn{2}{|c|}{\begin{tabular}{c} 
in \\
\multicolumn{2}{|c|}{}
\end{tabular}} & 0 & 0.25 & 0.50 \\
\hline \multirow{2}{*}{$\begin{array}{c}\text { Amount of } \\
\text { cement } \\
\text { in } 1 \mathrm{~m}^{3} \text { of } \\
\text { fresh concrete }\end{array}$} & 250 & $\mathrm{R}$ & - & - \\
\cline { 2 - 5 } & 300 & $0 / 1$ & $1 / 1$ & - \\
\cline { 2 - 5 } & 350 & $0 / 2$ & $1 / 2$ & $2 / 2$ \\
\hline
\end{tabular}


D. KOCÁB et al.: EXPERIMENTAL DETERMINATION OF THE INFLUENCE OF FRESH CONCRETE'S COMPOSITION ...

Table 2: Composition of the concrete mixtures in $1 \mathrm{~m}^{3}$ with the real values of amount of the components Tabela 2: Sestava mešanice betona $\mathrm{v} 1 \mathrm{~m}^{3}$, $\mathrm{z}$ realno vrednostjo količine komponente

\begin{tabular}{|c|c|c|c|c|c|c|c|c|c|c|}
\hline \multirow{2}{*}{\multicolumn{2}{|c|}{$\begin{array}{l}\text { Components per } 1 \mathrm{~m}^{3} \text { of fresh } \\
\text { concrete }\end{array}$}} & \multicolumn{9}{|c|}{ Concrete ID } \\
\hline & & $\mathrm{R}$ & $0 / 1$ & $0 / 2$ & $0 / 3$ & $1 / 1$ & $1 / 2$ & $1 / 3$ & $2 / 2$ & $2 / 3$ \\
\hline \multicolumn{2}{|c|}{ CEM I 42.5 R (Mokrá) (kg) } & 248 & 308 & 357 & 392 & 295 & 349 & 394 & 338 & 386 \\
\hline \multicolumn{2}{|c|}{ Sand (Bratčice) 0-4 (kg) } & 953 & 925 & 889 & 826 & 927 & 897 & 846 & 905 & 854 \\
\hline \multicolumn{2}{|c|}{ Aggregate (Olbramovice) 4-8 (kg) } & 173 & 182 & 174 & 195 & 185 & 185 & 192 & 183 & 207 \\
\hline \multicolumn{2}{|c|}{ Aggregate (Olbramovice) $8-16(\mathrm{~kg})$} & 675 & 696 & 693 & 669 & 689 & 693 & 684 & 667 & 671 \\
\hline \multirow{3}{*}{ Water $(\mathrm{kg})$} & mixing & 187 & 189 & 188 & 195 & 163 & 162 & 170 & 163 & 168 \\
\hline & in aggregate & 14 & 14 & 13 & 13 & 14 & 13 & 13 & 13 & 13 \\
\hline & total & 201 & 203 & 201 & 208 & 177 & 175 & 183 & 176 & 181 \\
\hline \multicolumn{2}{|c|}{ Sika ViscoCrete $4035(\mathrm{~kg})$} & 0 & 0 & 0 & 0 & 0.71 & 0.91 & 0.95 & 1.77 & 2.01 \\
\hline \multicolumn{2}{|c|}{$W / C$ ratio $\left(w_{\text {mixing }} /\right.$ cement $)(-)$} & 0.75 & 0.61 & 0.53 & 0.50 & 0.55 & 0.46 & 0.43 & 0.44 & 0.44 \\
\hline
\end{tabular}

throughout their volume, all the concrete mixtures were produced in a concrete mixing tower, which is the cause for the slight differences in the composition of the fresh concretes. For clarity, Table 2 shows the detailed composition of the fresh concretes and Table 3 contains the basic properties of the fresh and hardened concretes determined in accordance with the standards of the issue ČSN EN $12350{ }^{28}$ and ČSN EN $12390{ }^{29}$.

Table 3: Properties of fresh and hardened concrete

Tabela 3: Lastnosti svežega in strjenega betona

\begin{tabular}{|c|c|c|c|c|}
\hline $\begin{array}{c}\text { Concrete } \\
\text { mixture }\end{array}$ & $\begin{array}{c}\text { Slump } \\
\text { test } \\
(\mathrm{mm})\end{array}$ & $\begin{array}{c}\text { Flow } \\
\text { table } \\
\text { test } \\
(\mathrm{mm})\end{array}$ & $\begin{array}{c}\text { Bulk density of } \\
\text { fresh concrete } \\
\left(\mathrm{kg} / \mathrm{m}^{3}\right)\end{array}$ & $\begin{array}{c}\text { Compressive } \\
\text { strength of } \\
\text { hardened concrete } \\
\left(\mathrm{N} / \mathrm{mm}^{2}\right)\end{array}$ \\
\hline $\mathrm{R}$ & 110 & 440 & 2250 & 21.6 \\
\hline $0 / 1$ & 60 & 410 & 2320 & 33.3 \\
\hline $0 / 2$ & 60 & 390 & 2320 & 44.5 \\
\hline $0 / 3$ & 110 & 420 & 2290 & 55.8 \\
\hline $1 / 1$ & 60 & 360 & 2280 & 42.8 \\
\hline $1 / 2$ & 50 & 350 & 2300 & 50.8 \\
\hline $1 / 3$ & 60 & 370 & 2300 & 56.4 \\
\hline $2 / 2$ & 70 & 340 & 2270 & 52.2 \\
\hline $2 / 3$ & 50 & 330 & 2300 & 57.2 \\
\hline
\end{tabular}

Test specimens were made from the mixtures for the purposes of the experiment according to method $\mathrm{A}$ and method C..$^{20}$ The specimens were cured under water until the time of the tests had arrived. The result of both tests was the average number of cycles necessary for the scaled off material to weigh $1000 \mathrm{~g} / \mathrm{m}^{2}$ and $3000 \mathrm{~g} / \mathrm{m}^{2}$ (i.e., the D1 and D3 coefficients) for each concrete of every mixture. In the case of method $C$, the D5 coefficient was also determined, i.e., the number of cycles necessary for scale-off amounting to $5000 \mathrm{~g} / \mathrm{m}^{2}$. At the beginning of the experiment, the number of loading cycles was set to be 100 for both methods. In the case of some specimens, the damage was so severe that the specimens were loaded for a lower number of cycles given the high values of scale-off.

\section{RESULTS AND DISCUSSION}

3 In order to assess the influence of the composition of concrete on the results of tests of its resistance to water and de-icing chemicals, a statistical analysis of the experiment was performed using the techniques of the DOE method. In order to model the dependence of the test results on the input factors, i.e., the components of fresh concretes, three basic models were used: linear, linear with interactions and a model with both a linear and quadratic representation of the factor effects including their mutual interactions. More can be found, e.g., in ${ }^{35}$. During the DOE, the following factors were chosen, which can be assumed to have had an influence on the resistance of the surface layer to defrosting chemicals: the amount of cement and plasticiser, while another factor was added during the evaluation water/cement $(w / c)$ ratio.

\subsection{Results for method $A$}

Table 4 contains the results of tests performed using method A described in ${ }^{20}$ with all the specimens of all the mixtures being examined. The coefficients being observed were D1 and D3.

Table 4: Evaluation of coefficients D1 and D3 according to method A of ${ }^{20}$ for each specimen of each mixture

Tabela 4: Ocena koeficientov D1 in D3 po metodi A ${ }^{20}$, za vsak vzorec vsake mešanice

\begin{tabular}{|l|c|c|c|c|c|c|c|c|c|}
\hline \multicolumn{1}{|c|}{ Mixture } & $\mathbf{R}$ & $\mathbf{0 / 1}$ & $\mathbf{0 / 2}$ & $\mathbf{0 / 3}$ & $\mathbf{1 / 1}$ & $\mathbf{1 / 2}$ & $\mathbf{1 / 3}$ & $\mathbf{2 / 2}$ & $\mathbf{2 / 3}$ \\
\hline \multirow{2}{*}{$\begin{array}{l}\text { D1 coefficient } \\
\text { (number of cycles) }\end{array}$} & 6 & 13 & 12 & 10 & 9 & 23 & 12 & 32 & 16 \\
\cline { 2 - 10 } & 7 & 12 & 12 & 9 & 8 & 24 & 12 & 29 & 13 \\
\hline $\begin{array}{l}\text { Average value of } \\
\text { the D1 coefficient }\end{array}$ & $\mathbf{5}$ & $\mathbf{1 2}$ & $\mathbf{1 2}$ & $\mathbf{1 0}$ & $\mathbf{9}$ & $\mathbf{2 3}$ & $\mathbf{1 3}$ & $\mathbf{3 1}$ & $\mathbf{1 6}$ \\
\hline \multirow{2}{*}{$\begin{array}{l}\text { D3 coefficient } \\
\text { (number of cycles) }\end{array}$} & 17 & 27 & 30 & 28 & 26 & 42 & 33 & 60 & 39 \\
\cline { 2 - 10 } & 11 & 27 & 27 & 29 & 24 & 38 & 37 & 57 & 44 \\
\hline $\begin{array}{l}\text { Average value of } \\
\text { the D3 coefficient }\end{array}$ & $\mathbf{1 6}$ & $\mathbf{2 7}$ & $\mathbf{2 8}$ & $\mathbf{2 8}$ & $\mathbf{2 5}$ & $\mathbf{4 1}$ & $\mathbf{3 4}$ & $\mathbf{5 7}$ & $\mathbf{3 9}$ \\
\hline
\end{tabular}

The Pareto analysis of the results of the ANOVA (Analysis of Variance) statistical tests performed on significance level of 0.05 is shown in Figures $\mathbf{1}$ and 2. 
D. KOCÁB et al.: EXPERIMENTAL DETERMINATION OF THE INFLUENCE OF FRESH CONCRETE'S COMPOSITION ...

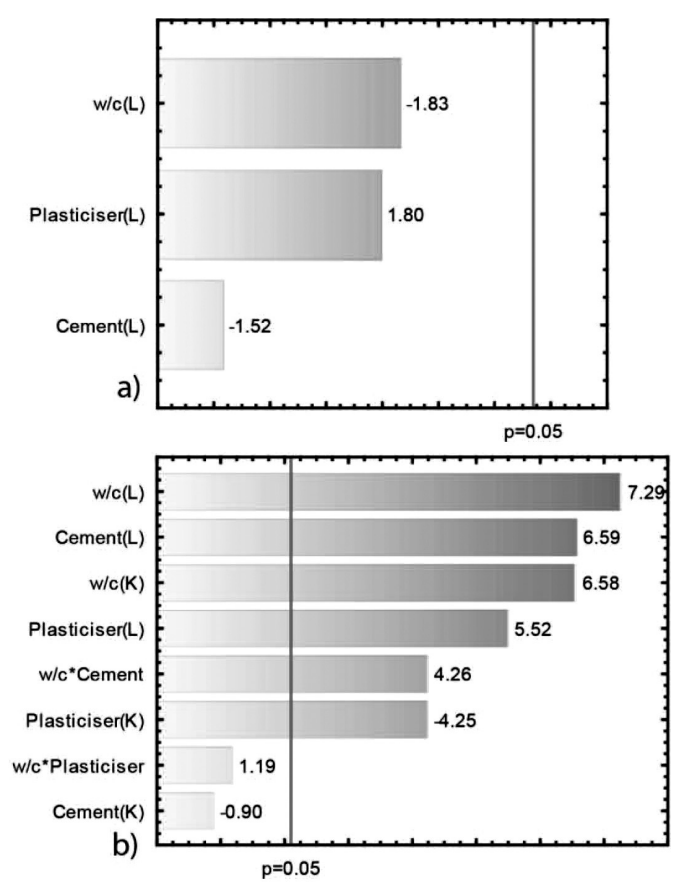

Figure 1: Method A, D1 coefficient: a) Pareto diagram of the standardised assessment of effects - linear model, b) Pareto diagram of the standardised assessment of effects - each effect represented in linear $(\mathrm{L})$ and quadratic form $(\mathrm{K})$

Slika 1: Metoda A, koeficient D1: a) Pareto diagram standardiziranega ugotavljanja učinkov - linearni model, b) Pareto diagram standardiziranega ugotavljanja učinkov - vsak učinek je predstavljen v linearni (L) in v kvadratni (K) obliki

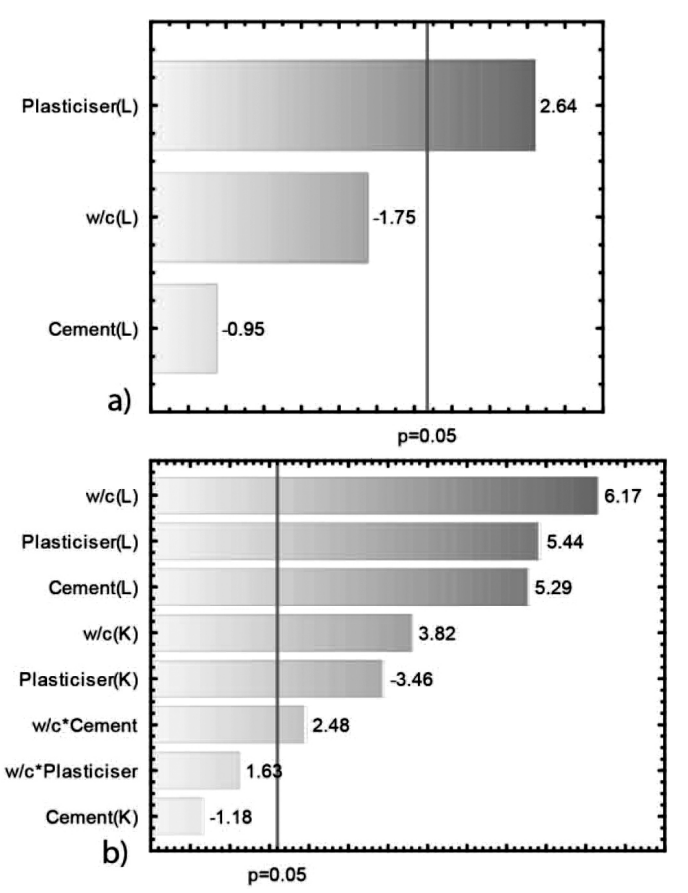

Figure 2: Method A, D3 coefficient: a) Pareto diagram of the standardised assessment of effects - linear model, b) Pareto diagram of the standardised assessment of effects - each effect represented in linear $(\mathrm{L})$ and quadratic form $(\mathrm{K})$

Slika 2: Metoda A, koeficient D3: a) Pareto diagram standardiziranega ugotavljanja učinkov - linearni model, b) Pareto diagram standardiziranega ugotavljanja učinkov - vsak učinek je predstavljen v linearni (L) in v kvadratni (K) obliki
These statistical tests compared the statistical significances of the standardised assessments of the individual factor effects ( $w / c$ ratio, cement content and plasticiser content). Generally speaking, it was the statistical influence of concrete composition on test results - i.e., the values of the D1 and D3 coefficients. Figures 1a and $\mathbf{2 a}$ show the results of the purely linear model and Figure $\mathbf{1 b}$ and $\mathbf{2 b}$ show the results of the model with a linear and quadratic representation of effects including mutual interactions.

Based on these results, it appears difficult to analyse the most substantial influence in the composition of concrete on its resistance to de-icing agents using method A. None of the factor effects or their interaction has a more significant influence than any of the others. However, based on the linear model and the complete model with the quadratic representation of all the effects and interactions, it can be said that the slightly more significant factor influencing the value of the D1 coefficient is the w/c ratio. In the case of the D1 and D3 coefficients, the results do not confirm the assumption that higher cement content brings greater resistance of concrete cover to the attack of de-icing chemicals with any plasticiser content. The positive influence of an increase in plasticiser content is more visible in the results in Table 3. This fact is confirmed also in ${ }^{36}$ which deals with testing by means of CDF, which is in principle identical to method $\mathrm{A}^{20}$. The paper ${ }^{36}$ contains the results for four types of concrete differing, among others, in the plasticiser content. Compared with the concretes containing additives, the de-icing-chemical resistance of the concrete with no plasticiser was lower by several orders of magnitude. The article ${ }^{37}$ describes the same tendency in the behaviour of concretes with a different content of additives in relation to their resistance to water and de-icing chemicals. The results in ${ }^{37}$ are supplemented with another parameter, which is the assessment of the influence of air-entrainment on the behaviour of concrete

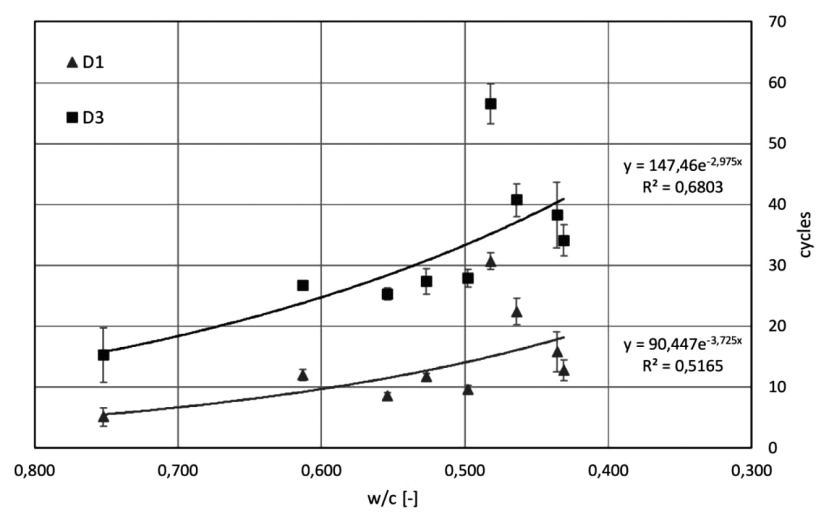

Figure 3: Dependence of average D1 and D3 coefficients according to method $\mathrm{A}^{20}$ on w/c ratio, including corrected sample standard deviations

Slika 3: Odvisnost povprečja koeficientov D1 in D3 po metodi $\mathrm{A}^{20}$ na razmerje w/c, z vključenim korigiranim standardnim odstopanjem vzorca 


\section{MATERIALI IN TEHNOLOGIJE/MATERIALS AND TECHNOLOGY (1967-2017) - 50 LET/50 YEARS}

\section{KOCÁB et al.: EXPERIMENTAL DETERMINATION OF THE INFLUENCE OF FRESH CONCRETE'S COMPOSITION ...}

during the CDF test. The issue of the resistance of concrete to water and de-icing chemicals is also discussed in ${ }^{38}$, where the matter being tested is the de-icing-chemical resistance of concretes with a different plasticiser content (as well as silica fume and an air-entraining additive). The present issue is also addressed in ${ }^{39-41}$.

Figure 3 shows the dependence of the D1 and D3 values on the $w / c$ ratio. It is apparent that as the $w / c$ ratio is decreased, the resistance of concrete to de-icing agents increases.

\subsection{Results for method C}

Table 5 contains the results of tests performed using method $\mathrm{C}$ described in ${ }^{20}$ with all the specimens of all the mixtures being examined. The coefficients being observed were D1, D3 and D5.

Table 5: Evaluation of coefficient D1, D3 and D5 according to method $\mathrm{C}$ of ${ }^{20}$ for each specimen of each mixture

Tabela 5: Ocena koeficientov D1, D3 in D5 po metodi $C^{20}$, za vsak vzorec vsake mešanice

\begin{tabular}{|l|c|c|c|c|c|c|c|c|c|}
\hline \multicolumn{1}{|c}{ Mixture } & $\mathbf{R}$ & $\mathbf{0 / 1}$ & $\mathbf{0 / 2}$ & $\mathbf{0 / 3}$ & $\mathbf{1 / 1}$ & $\mathbf{1 / 2}$ & $\mathbf{1 / 3}$ & $\mathbf{2 / 2}$ & $\mathbf{2 / 3}$ \\
\hline \multirow{2}{*}{$\begin{array}{l}\text { D1 coefficient } \\
\text { (number of cycles) }\end{array}$} & 2 & 2 & 4 & 10 & 4 & 7 & 71 & 25 & 44 \\
\cline { 2 - 10 } & 2 & 2 & 4 & 9 & 5 & 7 & 77 & 28 & 36 \\
\cline { 2 - 10 } & 2 & 2 & 4 & 8 & 4 & 6 & 83 & 26 & 41 \\
\hline $\begin{array}{l}\text { Average value of the } \\
\text { D1 coefficient }\end{array}$ & $\mathbf{2}$ & $\mathbf{2}$ & $\mathbf{4}$ & $\mathbf{9}$ & $\mathbf{4}$ & $\mathbf{7}$ & $\mathbf{7 7}$ & $\mathbf{2 7}$ & $\mathbf{4 0}$ \\
\hline \multirow{2}{*}{$\begin{array}{l}\text { D3 coefficient } \\
\text { (number of cycles) }\end{array}$} & 6 & 5 & 13 & 28 & 11 & 22 & - & 42 & 66 \\
\cline { 2 - 10 } & 5 & 7 & 12 & 26 & 14 & 20 & - & 49 & 61 \\
\hline $\begin{array}{l}\text { Average value of the } \\
\text { D3 coefficient }\end{array}$ & $\mathbf{5}$ & $\mathbf{6}$ & $\mathbf{1 2}$ & $\mathbf{2 6}$ & $\mathbf{1 3}$ & $\mathbf{2 0}$ & - & $\mathbf{4 5}$ & $\mathbf{6 5}$ \\
\hline \multirow{2}{*}{$\begin{array}{l}\text { D5 coefficient } \\
\text { (number of cycles) }\end{array}$} & 9 & 9 & 22 & 40 & 19 & 35 & - & 58 & 82 \\
\cline { 2 - 10 } & 8 & 12 & 20 & 38 & 24 & 33 & - & 62 & 78 \\
\hline $\begin{array}{l}\text { Average value of the } \\
\text { D5 coefficient }\end{array}$ & $\mathbf{9}$ & $\mathbf{1 0}$ & $\mathbf{2 1}$ & $\mathbf{3 9}$ & $\mathbf{2 1}$ & $\mathbf{3 4}$ & - & $\mathbf{6 1}$ & $\mathbf{8 2}$ \\
\hline
\end{tabular}

The Pareto analysis of the results of the ANOVA (Analysis of Variance) statistical tests performed on the significance level of 0.05 is shown visually in Figures 4 through 6. Two models were chosen for the analysis of the tests performed by means of method $\mathrm{C}^{20}$ - linear and linear with interactions of the factor effects. Some interactions are in mutual linear combination and were therefore eliminated from the experiment.

Table 5 shows that the results for mixture $1 / 3$ are outliers. After 100 freeze-thaw cycles, the concrete suffered a scale-off corresponding to the D1 coefficient $\left(1000 \mathrm{~g} / \mathrm{m}^{2}\right)$, which indicates a much greater resistance of the surface layer to the action of de-icing chemicals compared with concretes of a similar composition. After a preliminary analysis, these results clearly influenced the overall outcomes. Figures $\mathbf{4 a}$ and $\mathbf{4 b}$ show the Pareto analysis of the test statistics for the D1 coefficient, which does not correspond to similar results for the D3 and D5 coefficients (Figures 5 and 6). After the elimination of
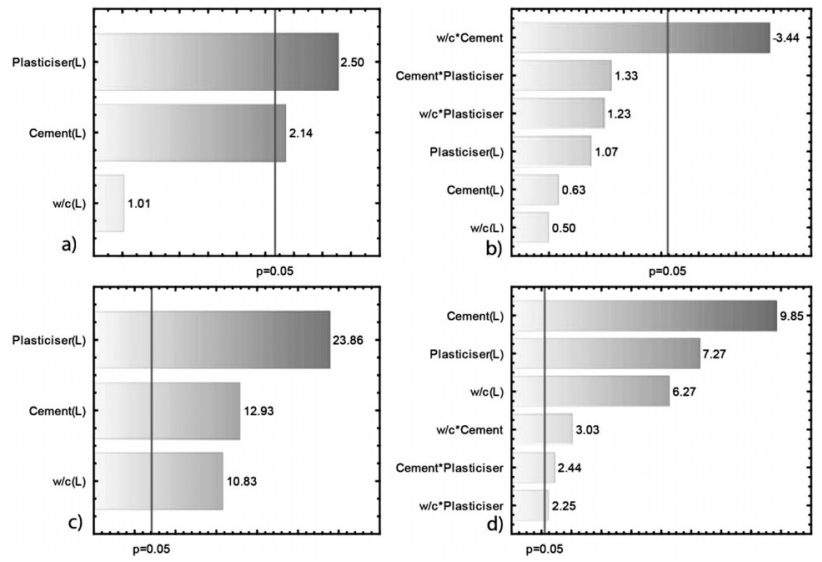

Figure 4: Method C, D1 coefficient: a) Pareto diagram of the standardised assessment of effects - linear model, b) Pareto diagram of the standardised assessment of effects - linear model with interactions, c) Pareto diagram of the standardised assessment of effects linear model - without results for mixture 1/3, d) Pareto diagram of the standardised assessment of effects - linear model with interactions - without results for mixture $1 / 3$

Slika 4: Metoda C, koeficient D1: a) Pareto diagram standardiziranega ugotavljanja učinkov - linearni model, b) Pareto diagram standardiziranega ugotavljanja učinkov - linearni model z interakcijami, c) Pareto diagram standardiziranega ugotavljanja učinkov - linearni model - brez rezultatov za mešanico $1 / 3$, d) Pareto diagram standardiziranega ugotavljanja učinkov - linearni model z interakcijo - brez rezultatov za mešanico $1 / 3$

the results for mixture $1 / 3$, the Pareto analysis of the D1 coefficient corresponds to the analysis of the D3 and D5 coefficients (Figures $\mathbf{4 c}$ and $\mathbf{4 d}$ ).

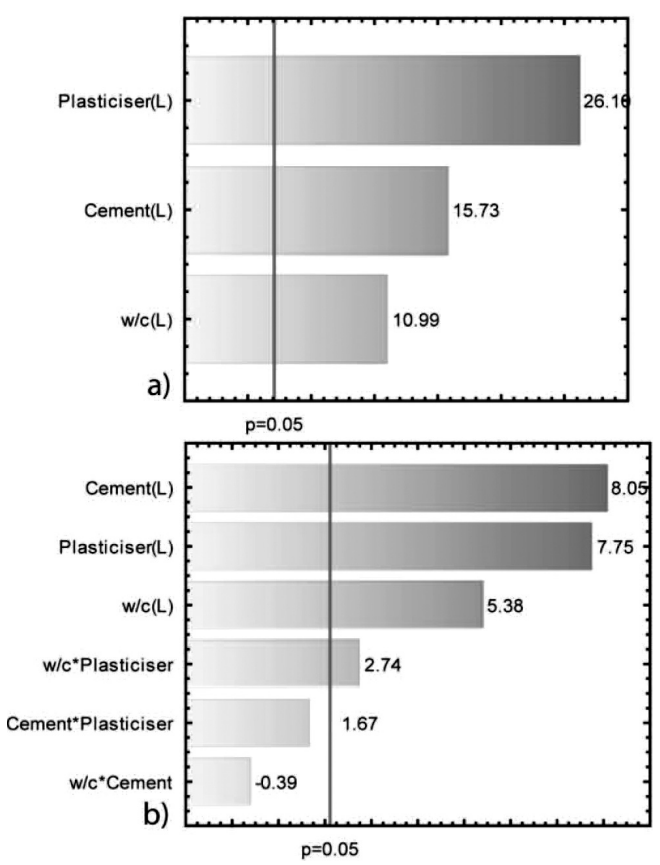

Figure 5: Method C, D3 coefficient: a) Pareto diagram of the standardised assessment of effects - linear model, b) Pareto diagram of the standardised assessment of effects - linear model with interactions

Slika 5: Metoda C, koeficient D3: a) Pareto diagram standardiziranega ugotavljanja učinkov - linearni model, b) Pareto diagram standardiziranega ugotavljanja učinkov - linearni model z interakcijami 
D. KOCÁB et al.: EXPERIMENTAL DETERMINATION OF THE INFLUENCE OF FRESH CONCRETE'S COMPOSITION ...

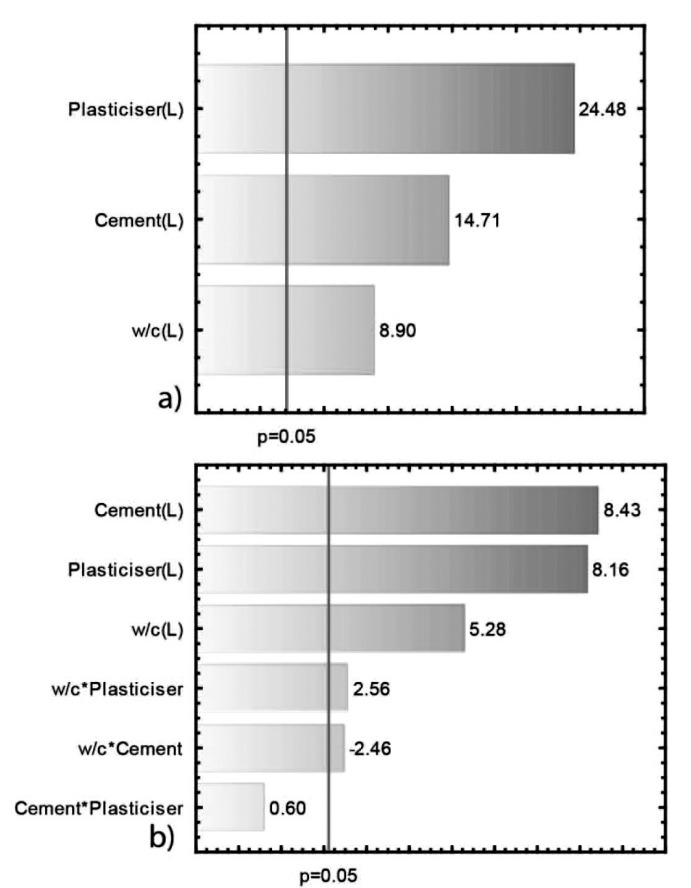

Figure 6: Method C, D5 coefficient: a) Pareto diagram of the standardised assessment of effects - linear model, b) Pareto diagram of the standardised assessment of effects - linear model with interactions

Slika 6: Metoda C, koeficient D5: a) Pareto diagram standardiziranega ugotavljanja učinkov - linearni model, b) Pareto diagram standardiziranega ugotavljanja učinkov - linearni model z interakcijami

Based on the analyses, it can be said that the results of the tests performed using method $\mathrm{C}$ from 20 exhibit significant statistical changes, especially in relation to the cement and plasticiser content. Figure 7 shows the assessment of the D5 coefficient on these two factors with an average $w / c$ ratio, which confirms the above-

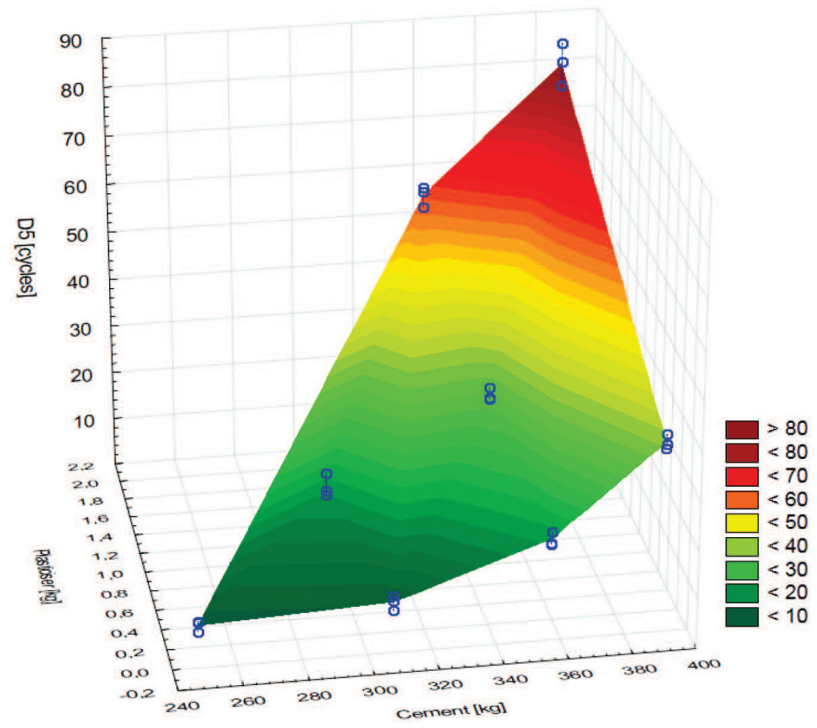

Figure 7: Dependence of the D5 coefficient according to method C 20 on cement and plasticiser content at an average w/c ratio Slika 7: Odvisnost koeficienta D5 po metodi C ${ }^{20}$ od vsebnosti cementa in plastifikatorja pri povprečnem razmerju w/c

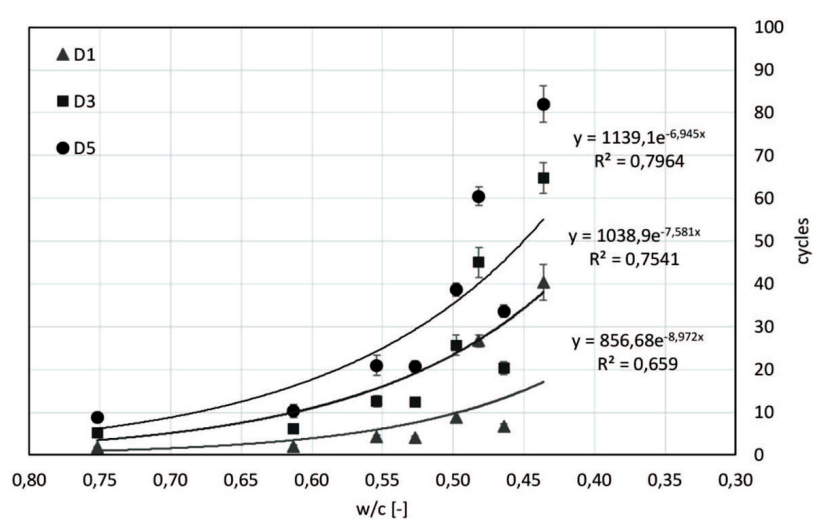

Figure 8: Dependence of the average D1, D3 and D5 coefficients according to method $\mathrm{C}^{20}$ on the w/c ratio (after the elimination of results for mixture 1/3), including corrected sample standard deviations

Slika 8: Odvisnost povprečja koeficientov D1, D3 in D5 po metodi $\mathrm{C}^{20}$ od razmerja w/c (po odstranitvi rezultatov za mešanico 1/3), vključujoč korigirana standardna odstopanja vzorca

mentioned findings. Figure 8 shows, similarly to method $\mathrm{A}^{20}$, the dependence of the D1, D3 and D5 coefficients on the $w / c$ ratio. The test results show the same trends as the previous case; it is, however, necessary to note the high variability of results in relation to the $w / c$ ratio.

In ${ }^{42}$ the authors discuss, among others, the results of concrete resistance tested by the scaling method according to ${ }^{18}$ on concretes of different composition, which is in principle comparable to method $\mathrm{C}$. The test results published in ${ }^{42}$ did not show clear tendencies of higher concrete resistance in dependence on increasing plasticiser content in fresh concrete, as opposed to the analysis performed by the authors of this paper. Also, method C is in principle identical to the method in ${ }^{23}$, which was used by the authors of the paper ${ }^{43}$, where the subject being investigated was how a partial substitution of cement with blast furnace slag (or fly ash) impacts the final resistance of concrete to de-icing chemicals. Next to the finding that the fly ash substantially worsens durability, the authors of ${ }^{43}$ arrived at the conclusion that the visual assessment of scale-off is very subjective and it would be appropriate to substitute it with determining the damage to the concrete surface by weighing the scaled-off material. Similarly, the authors of ${ }^{44}$ prefer measuring the mass of the scale-off, which corresponds to the experience of this paper's authors as well. The similar issue of determining the resistance of concrete to de-icing chemicals is also addressed in the papers. ${ }^{45-47}$

\section{CONCLUSION}

The assessment of the durability of concrete through testing its surface layer for damage by de-icing chemicals is very sensitive to a number of factors, whether technological (fresh concrete composition) or test ones (choice of method, means of specimen treatment, etc.), which is confirmed by the conclusions published, e.g., in ${ }^{37,42,43,45,47}$. The results of the experi- 


\section{KOCÁB et al.: EXPERIMENTAL DETERMINATION OF THE INFLUENCE OF FRESH CONCRETE'S COMPOSITION ...}

ment described in this paper suggest that the composition of fresh concrete has a demonstrable influence on the resistance of the concrete surface layer to the action of de-icing chemicals. It can be said that performing the laboratory tests using method $\mathrm{C}^{20}$, the coefficients of concrete resistance to de-icing chemicals reach lower values and thus it appears that the surface layer is less durable compared with the case when method $\mathrm{A}^{20}$ is used. The reason may be a different direction in which the solution acts upon the specimen (the specimen being immersed vs. the solution being poured onto the specimen), different time of the attack by extreme temperatures, etc. The change in the amount of cement and the amount of plasticiser in fresh concrete is more conclusively visible in the test results according to method C20, which is in principle similar to the scaling methods in ${ }^{18}$ and ASTM. ${ }^{23}$ The measurement results also indicated a greater sensitivity of method $\mathrm{C}^{20}$ to a change in the $w / c$ ratio of fresh concrete.

\section{Acknowledgement}

This paper was written with the financial support of the Czech Science Foundation project GAČR 13-18870S and the European Union's "Operational Programme Research and Development for Innovations", No. CZ.1.05/2.1.00/03.0097.

\section{REFERENCES}

${ }^{1}$ B. Piwakowski, M. Kaczmarek, P. Safinowski, Evaluation of concrete cover by surface wave technique: Identification procedure, (2011), 276-279, doi:10.1063/1.3703188

${ }^{2}$ L. H. R. Lackner, P. Pimienta, F. Meftah, Permeability of concrete under thermal and compressive stress influence; an experimental study, MATEC Web of Conferences, 6 (2013), 03007, doi:10.1051/ matecconf/20130603007

${ }^{3}$ V. Cnudde, A. Cwirzen, B. Masschaele, P. J. S. Jacobs, Porosity and microstructure characterization of building stones and concretes, Engineering Geology, 103 (2009) 3-4, 76-83, doi:10.1016/j.enggeo. 2008.06.014

${ }^{4}$ B. Kucharczyková, P. Misák, T. Vymazal, Determination and evaluation of the air permeability coefficient using Torrent Permeability Tester, Russian Journal of Nondestructive Testing, 46 (2010) 3, 226-233, doi:10.1134/S1061830910030113

${ }^{5}$ M. Stehlík, V. Hermánková, L. Vítek, Opening of microcracks and air permeability in concrete, Journal of Civil Engineering and Management, 21 (2015) 2, 177-184, doi:10.3846/13923730.2013. 802721

${ }^{6}$ J. Liu, F. Xing, B. Dong, H. Ma, D. Pan, Study on Surface Permeability of Concrete under Immersion, Materials, 7 (2014) 2 , 876-886, doi:10.3390/ma7020876

${ }^{7}$ H. Seleem, A. Rashad, B. El-Sabbagh, Durability and strength evaluation of high-performance concrete in marine structures, Construction and Building Materials, 6 (2010) 24, 878-884, doi:10.1016/j.conbuildmat.2010.01.013. ISSN 09500618

${ }^{8}$ T. Stavař, M. Stehlík, The Assessment of Durability of Fibre Concretes with Dense Aggregate and Concrete Recyclate from the Results of Permeability and Diffusion Tests, Advanced Materials Research, 1100 (2015), 106-111, doi:10.4028/www.scientific.net/ AMR.1100.106
${ }^{9}$ M. Stehlík, Enhancing the durability of concrete made of concrete recyclate by additives and admixtures, Journal of Civil Engineering and Management, 2 (2014) 20, 270-279, doi:10.3846/13923730. 2013.802708

${ }^{10}$ J. Valenza, G. Scherer, A review of salt scaling: I. Phenomenology, Cement and Concrete Research, 37 (2007) 7, 1007-1021, doi:10.1016/j.cemconres.2007.03.005

${ }^{11}$ Z. Liu, W. Hansen, Freezing characteristics of air-entrained concrete in the presence of deicing salt, Cement and Concrete Research, 74 (2015), 10-18, doi:10.1016/j.cemconres.2015.03.015

${ }^{12} \mathrm{~J}$. Valenza, G. Scherer, Mechanism for salt scaling of a cementitious surface, Materials and Structures, 40 (2007) 3, 259-268, doi:10.1617/s11527-006-9104-1

${ }^{13}$ Freeze-thaw and de-icing resistance of concrete, Essen: Lund Institute of Technology, 1992

${ }^{14} \mathrm{H}-\mathrm{S}$. Shang, T-H Yi, Freeze-Thaw Durability of Air-Entrained Concrete, The Scientific World Journal, (2013), 1-6, doi:10.1155/2013/650791. ISSN 1537744x

${ }^{15}$ V. Penttala, Surface and internal deterioration of concrete due to saline and non-saline freeze-thaw loads, Cement and Concrete Research, 36 (2006) 5, 921-928, doi:10.1016/j.cemconres.2005. 10.007

${ }^{16}$ Z. Sun, G. Scherer, Effect of air voids on salt scaling and internal freezing, Cement and Concrete Research, 40 (2010) 2, 260-270, doi:10.1016/j.cemconres.2009.09.027

${ }^{17}$ P-C. Aïtcin, Vysokohodnotný beton. 1. české vyd. Praha: Pro Českou komoru autorizovaných inženýrů a techniků činných ve výstavbě (ČKAIT) a Českou betonářskou společnost vydalo Informační centrum ČKAIT, 2005, Betonové stavitelství

${ }^{18}$ CEN/TS 12390-9, CEN/TS 12390-9 Testing hardened concrete, Freeze-thaw resistance, Scaling, European Committee for Standardization, 2006

${ }^{19}$ Concrete testing - Hardened concrete - Scaling at freezing, Swedish: Swedish Standards Institution, 2005

${ }^{20}$ ČSN 731326 Stanovení odolnosti povrchu cementového betonu proti působení vody a chemických rozmrazovacích látek, Praha: Úřad pro normalizaci a měření, 1984

${ }^{21}$ ČSN 731380 Zkoušení odolnosti betonu proti zmrazování a rozmrazování - Porušení vnitřní struktury, Praha: Český normalizační institut, 2007

${ }^{22}$ ČSN 73 1322, ČSN 731322 Stanovení mrazuvzdornosti betonu, Praha, Úřad pro normalizaci a měření, 1968

${ }^{23}$ Standard Test Method for Scaling Resistance of Concrete Surfaces Exposed to Deicing Chemicals, West Conshohocken, PA: ASTM International, 2012

${ }^{24}$ J. Valenza, G. W. Scherer, A review of salt scaling: II. Mechanisms, Cement and Concrete Research, 37 (2007) 7, 1022-1034 doi:10.1016/j.cemconres.2007.03.003

${ }^{25}$ J. Kim, J. H. Moon,J. W. Shim,J. Sim,H. G. Lee, G. Zi, Durability properties of a concrete with waste glass sludge exposed to freezeand-thaw condition and de-icing salt, Construction and Building Materials, 66 (2014), 398-402, doi:10.1016j.conbuildmat.2014. 05.081

${ }^{26}$ BAW Code of Practice: Frost Resistance Tests for Concrete (MFB), Karlsruhe: Bundesanstalt für Wasserbau (BAW), 2012

${ }^{27}$ CSN EN 12350 Testing of fresh concrete: this standard is the Czech version of the European Standard EN 12350, Praha: ÚNMZ, 2009

${ }^{28}$ CSN EN 12390 Testing hardened concrete: this standard is the Czech version of the European Standard EN 12390, Praha: ÚNMZ, 2009

${ }^{29}$ H. Šimonová, I. Havlíková, P. Daněk, Z. Keršner, T. Vymazal, The Effect of a Superplasticizer Admixture on the Mechanical Fracture Parameters of Concrete, Mater. Tehnol., 49 (2015) 3, 417-421, doi:10.17222/mit.2014.114

${ }^{30}$ H. Šimonová, D. Lehký, Z. Keršner, V. Veselý, J. Macur, Relationships Between Mechanical Fracture and Durability Parameters of Selected Concretes, 39th Solid Mechanics Conference Book of 


\section{MATERIALI IN TEHNOLOGIJE/MATERIALS AND TECHNOLOGY (1967-2017) - 50 LET/50 YEARS}

\section{KOCÁB et al.: EXPERIMENTAL DETERMINATION OF THE INFLUENCE OF FRESH CONCRETE'S COMPOSITION ...}

Abstracts, Warszawa: Institute of Fundamental Technological Research PAN, (2014), 51-52

${ }^{31}$ H. Šimonová, I. Havlíková, P. Daněk , D. Lehký, B. Kucharczyková, Z. Keršner, Study of Influence of Cement Dosage on Mechanical Fracture Parameters of Selected Concretes, In Proc. of the 6 th Int. Conf. on Dynamics of Civil Engineering and Transport Structures and Wind Engineering. Žilina, EDIS publishing house University of Zilina, (2014), 291-296

${ }^{32}$ M. Matysík, L. Topolar, P. Daněk, T. Vymazal, I. Plšková, The Effect of Concrete Quality on the Acoustic Emission Parameters during Three-Point Bending Fracture Test, Advanced Materials Research, 897 (2014), 149-152, doi:10.4028/www.scientific.net/AMR.897.149

${ }^{33}$ T. Komárková, M. Králíková, P. Kovács, Application of computed tomography in comparison with the standardized methods for determining the permeability of cement-composite structures, Mater. Tehnol., 49 (2015) 4, 587-595, doi:10.17222/mit.2014.194

${ }^{34}$ L. Eriksson, N. Kettaneh-Wold, C. Wikström, S. Wold, Design Of Experiments: Principles And Applications. 3. revised and enlarged, Umeå: MKS Umetrics AB, 2008

${ }^{35}$ J. Deja, Freezing and de-icing salt resistance of blast furnace slag concretes. Cement and Concrete Composites, 25 (2003) 3, 357-361, doi:10.1016/S0958-9465(02)00052-5

${ }^{36}$ R. Şahin, M. Taşdemir, R. Gül, C. Çelik, Determination of the optimum conditions for de-icing salt scaling resistance of concrete by visual examination and surface scaling, Construction and Building Materials, 24 (2010) 3, 353-360, doi:10.1016/j.conbuildmat. 2009.08.026

${ }^{37}$ H. Romero, A. Enfedaque, J. Gálvez, M. Casati, Resistencia del hormig\&amp;\#243;n frente a ciclos hielo deshielo medida con t\&amp;\#233; cnicas complementarias. Materiales de Construcción, 65 (2015) 317, 048-, doi:10.3989/mc.2015.01514

${ }^{38}$ Z. Van, G. F. Wittmann, B. Oh, Durability of strain-hardening cement-based composites (SHCC), Materials and Structures, 45 (2012) 10, 1447-1463, doi:10.1617/s11527-012-9845-y
${ }^{39}$ P. A. G. V. Zijl, Gideon, F. H. Wittmann, On Durability of SHCC, Journal of Advanced Concrete Technology, 8 (2010) 3, 261-271, doi: $10.3151 /$ jact. 8.261

${ }^{40}$ J. Zhang, P. C. Taylor, C. Shi, Investigation of approaches for improving interfacial transition zone-related freezing-and-thawing resistance in concrete pavements. ACI Materials Journal, 112 (2015) 5, 613-617. doi:10.14359/51687902

${ }^{41}$ T. Rønning, Freeze-Thaw Resistance of Concrete Effect of: Curing Conditions, Moisture Exchange and Materials, Doctoral thesis,Fakultet for ingeniørvitenskap og teknologi Trondheim, 2011

${ }^{42}$ R. M. Ahani, M. R. Nokken, Salt scaling resistance - The effect of curing and pre-saturation, Construction and Building Materials, 26 (2012) 1, 558-564, doi:10.1016/j.conbuildmat.2011.06.058

${ }^{43}$ A. Ramezanianpour, M. J. Nadooshan, M. Peydayesh, A. M. Ramezanianpour, Effect of entrained air voids on salt scaling resistance of concrete containing a new composite cement, KSCE Journal of Civil Engineering, 18 (2014) 1, 213-219, doi:10.1007/s12205-014-0365-X

${ }^{44}$ A. Ramezanianpour, M. J. Nadooshan, M. Peydayesh, Effect of New Composite Cement Containing Volcanic Ash and Limestone on Mechanical Properties and Salt Scaling Resistance of Concrete, Journal of Materials in Civil Engineering, 25 (2013) 11, 1587-1593, doi:10.1061/(ASCE)MT.1943-5533.0000679

${ }^{45}$ M. Pigeon, C. Talbot, J. Marchand a H. Hornain, Surface microstructure and scaling resistance of concrete, Cement and Concrete Research, 26 (1996) 10, 1555-1566, doi:10.1016/0008-8846(96) 00138-X

${ }^{46}$ E. Houehanou, R. Gagné, M. Jolin, Analysis of the representativeness and relative severity of ASTM C672 and NQ 2621-900 standard procedures in evaluating concrete scaling resistance, Canadian Journal of Civil Engineering, 37 (2010) 11, 1471-1482, doi:10.1139/L10-091 